\title{
Selective Antagonism of GluR5 Kainate-Receptor-Mediated Synaptic Currents by Topiramate in Rat Basolateral Amygdala Neurons
}

\author{
Divina S. Gryder and Michael A. Rogawski \\ Epilepsy Research Section, National Institute of Neurological Disorders and Stroke, National Institutes of Health, Bethesda, Maryland 20892-4457
}

\begin{abstract}
Topiramate is a widely used antiepileptic agent whose mechanism of action is poorly understood. The drug has been reported to interact with various ion channel types, including AMPA/kainate receptors. In whole-cell voltage-clamp recordings from principal neurons of the rat basolateral amygdala, topiramate at low concentrations $\left(\mathrm{IC}_{50}, \sim 0.5 \mu \mathrm{M}\right)$ selectively inhibited pharmacologically isolated excitatory synaptic currents mediated by kainate receptors containing the GluR5 subunit. Topiramate also partially depressed predominantly AMPA-receptor-mediated EPSCs, but with lower efficacy. Topiramate did not alter the degree of facilitation in paired-pulse experiments, and it reduced the amplitude of miniature EPSCs without affecting their frequency, demonstrating that the block of synaptic responses occurs postsynaptically. Inhibition of GluR5 kainate receptors could represent a key mechanism underlying the anticonvulsant activity of topiramate. Moreover, these results support the concept that GluR5 kainate receptors represent a novel target for antiepileptic drug development.
\end{abstract}

Key words: topiramate; kainate receptor; AMPA receptor; amygdala; synaptic current; patch-clamp recording

\section{Introduction}

Topiramate [2,3:4,5-bis-O-(1-methylethylidene)-36-D-fructopyranose sulfamate] is a structurally novel antiepileptic drug that is approved for use in the treatment of partial seizures, primary generalized seizures, and seizures associated with Lenox-Gastaut syndrome in children (Glauser, 1999; Jette et al., 2002). Several cellular mechanisms have been proposed to underlie the therapeutic activity of topiramate, including (1) activity-dependent attenuation of voltage-dependent sodium and calcium currents (Zona et al., 1997; Taverna et al., 1999; Zhang et al., 2000); (2) potentiation of $\mathrm{GABA}_{\mathrm{A}^{-}}$ receptor-mediated currents (White et al., 1997, 2000); and (3) inhibition of AMPA/kainate receptors (Gibbs et al., 2000; Skradski and White, 2000; Smith et al., 2000). The relative importance of any of these mechanisms in the clinical activity of topiramate is not well defined. Nonetheless, the potential action of topiramate on AMPA/ kainate receptors is intriguing inasmuch as drugs that block these receptors are highly effective in animal models used in the screening of antiepileptic drugs, but no other clinically used antiseizure medication targets these receptors at therapeutic concentrations (Rogawski, 2002).

The conclusion that topiramate blocks AMPA/kainate receptors is based on studies in cultured rat hippocampal neurons in which the drug was shown to produce a slow depression of inward currents activated by the perfusion of kainate but not NMDA (Gibbs et al., 2000). In addition, the drug blocked kainate-induced activation of AMPA/kainate receptors in cul-

Received March 4, 2003; revised June 9, 2003; accepted June 17, 2003.

Correspondence should be addressed to Dr. Michael A. Rogawski, Epilepsy Research Section, National Institute of Neurological Disorders and Stroke, National Institutes of Health, Building 49, Room 5A75, 49 Convent Drive MSC 4457, Bethesda, MD 20892-4457. E-mail: michael.rogawski@nih.gov.

Copyright $\odot 2003$ Society for Neuroscience $\quad$ 0270-6474/03/237069-06\$15.00/0 tured cerebellar granule neurons (Skradski and White, 2000). Kainate is an agonist of both AMPA and kainate receptors (Bleakman and Lodge, 1998), so it was not possible in these studies to distinguish between the effects of topiramate on these two receptor types.

We have recently demonstrated that electrical stimulation of afferents in the external capsule (EC) can evoke excitatory synaptic responses in principal neurons of the basolateral amygdala (BLA) that are mediated by multiple ionotropic excitatory amino acid receptors, including NMDA, AMPA, and kainate receptors (Li and Rogawski, 1998; Li et al., 2001). The various components of the excitatory synaptic response can be separated using selective pharmacological antagonists. In particular, the NMDAreceptor-mediated component can be blocked with $\mathrm{D}(-)-2-$ amino-5-phosphonopentanoic acid (AP5), and the AMPA component can be selectively reduced by appropriate concentrations of 2,3-benzodiazepines such as GYKI 52466 and GYKI 53655 (Paternain et al., 1995; Wilding and Huettner, 1995). In the presence of NMDA and AMPA receptor blockade, a component of the synaptic response remains that is sensitive to decahydroisoquinoline selective GluR5 kainate receptor antagonists. In the present study, we investigated the actions of topiramate on pharmacologically isolated synaptic responses mediated by AMPA and GluR5 kainate receptors. Our results demonstrate that the drug selectively blocks the GluR5 kainate-receptormediated component of the synaptic response through a postsynaptic mechanism.

\section{Materials and Methods}

Slice preparation and perfusion. Male 20- to 30-d-old Sprague Dawley rats were anesthetized with halothane and decapitated, and the brain was quickly removed and immersed in ice-cold $\left(4^{\circ} \mathrm{C}\right)$ sucrose-based artificial 
CSF (s-aCSF) solution containing the following (in mM): 200 sucrose, 3 $\mathrm{KCl}, 1.25 \mathrm{Na}_{2} \mathrm{PO}_{4}, 26 \mathrm{NaHCO}_{3}, 10$ glucose, $1 \mathrm{MgCl}_{2}$ and $2 \mathrm{CaCl}_{2}$ oxygenated with a mixture of $95 \% \mathrm{O}_{2}$ and $5 \% \mathrm{CO}_{2}, \mathrm{pH} 7.4,300 \mathrm{mOsm} / \mathrm{l}$. After incubating in the s-aCSF solution for $90 \mathrm{sec}$, the rostral portion of the brain was separated, by cutting with a razor blade just below the middle cerebral artery, and discarded. The hemispheres were then divided by a midsagittal cut; one hemisphere was temporarily returned to the s-aCSF bath and the other was glued to a glass Petri dish with the cut rostral surface down and the caudal end of the brain up. The brain was cut into $450 \mu \mathrm{m}$ thick sections using a vibrating slicer (Model 1000; Vibratome, St. Louis, MO) while being stabilized by a block of agar. The three slices containing the BLA immediately rostral to the lateral ventricles were collected for recording. An additional three slices were later obtained from the second hemisphere.

The slices were held for $1 \mathrm{hr}$ in an incubation chamber of warmed $\left(36^{\circ} \mathrm{C}\right)$, continuously oxygenated $\left(95 \% \mathrm{O}_{2}\right.$ and $\left.5 \% \mathrm{CO}_{2}\right)$ aCSF containing the following (in mM) $130 \mathrm{NaCl}, 3 \mathrm{KCl}, 1.25 \mathrm{Na}_{2} \mathrm{PO}_{4}, 26 \mathrm{NaHCO}_{3}, 10$ glucose, $1 \mathrm{MgCl}_{2}$, and $2 \mathrm{CaCl}_{2}, \mathrm{pH}$, 7.4. In experiments studying miniature EPSCs (mEPSCs), $1 \mu \mathrm{m}$ tetrodotoxin (Sigma, St. Louis, MO) was added to the perfusion solution. After recovery, individual slices were transferred to a recording chamber mounted on the stage of an upright microscope (Axioskop II; Zeiss, Thornwood, NJ). The slices were held in place with a $1 \mathrm{~mm}$ diameter platinum wire and were visualized by infrared differential interference contrast microscopy using a $40 \times$ waterimmersion objective. The recording chamber was continuously perfused at a rate of 3 to $4 \mathrm{ml} / \mathrm{min}$ with warmed aCSF $\left(31^{\circ} \mathrm{C}\right)$ using a gravity-fed fluid delivery system.

Whole-cell recording. Patch pipette electrodes were pulled from borosilicate glass tubing (M1B150F-4; World Precision Instruments, Sarasota, FL) and had a resistance of 5-7 M $\Omega$ when filled with intracellular solution consisting of the following (in $\mathrm{mM}$ ): 140 cesium methanesulfonate, $10 \mathrm{HEPES}, 10 \mathrm{EGTA}, 11 \mathrm{NaCl}, 0.5 \mathrm{CaCl}_{2}, 1 \mathrm{Mg}_{2} \mathrm{Cl}, 2 \mathrm{NaATP}$, and $0.2 \mathrm{NaGTP}, \mathrm{pH} 7.28,285 \mathrm{mOsm} / \mathrm{l}$. Lidocaine $\mathrm{N}$-ethyl bromide quaternary salt QX314 (5 mM) was added to the pipette solution to prevent the generation of $\mathrm{Na}^{+}$-dependent action potentials caused by a poor control of the membrane potential. Spermine $(100 \mu \mathrm{m})$ was also added to the intracellular recording solution to maintain adequate intracellular polyamines so as to preserve inward rectification of $\mathrm{Ca}^{2+}$-permeable AMPAand kainate-receptor-mediated currents (Donevan and Rogawski, 1995; Kamboj et al., 1995). The recording electrode was positioned near the white-matter tract demarcating the medial extent of the BLA. Tight-seal $(>10 \mathrm{G} \Omega$ ) whole-cell voltage-clamp recordings were obtained from the cell body of principal neurons in the BLA using an Axopatch 1D amplifier (Axon Instruments, Foster City, CA). The cell membrane was broken into at a holding potential of $-60 \mathrm{mV}$, and capacitance compensation was applied. Access resistance was regularly monitored. No cleaning of the cell somata was performed. Principal neurons were identified by oval-shaped soma, $\sim 10 \mu \mathrm{m}$ in the longest extent, and a large apical dendritic trunk arising from the soma. After tentative visual identification, principal neurons were further identified by the presence of spontaneous EPSCs at both negative $(-60 \mathrm{mV})$ and positive $(+60 \mathrm{mV})$ holding potentials (Mahanty and Sah, 1998). The identity of some neurons with these characteristics was confirmed morphologically after filling with $0.5 \%$ biocytin and processing as described by Tóth and McBain (1998).

Stimulation. Synaptic responses were evoked using a bipolar tungsten electrode (A-M Systems, Carlsborg, WA) placed in the EC (actually the amygdalar capsule, according to Swanson and Petrovich, 1998). The site of stimulation was at the inferiormost extent of the visible portion of the amygdalar capsule, immediately lateral to the BLA. Square, $100 \mu$ s duration unipolar pulses were applied via a constant-current isolation unit (Cygnus Technology, Delaware, PA) at an intensity of 700-900 $\mu \mathrm{A}$ to elicit a maximum synaptic response (typically $>500 \mathrm{pA}$ peak amplitude). The stimulation was routinely applied at $0.1 \mathrm{~Hz}$. After 25 consecutive responses showed no more than $10 \%$ variability in the peak amplitude of evoked responses, the solution was changed to one containing an antagonist mixture. Synaptic currents were routinely recorded at $-70 \mathrm{mV}$, except as noted.

Isolation of kainate and AMPA receptor currents. Kainate-receptor- mediated currents were isolated by switching to aCSF supplemented with the following (in $\mu \mathrm{M}$ ): 100 AP5 (Tocris Cookson, St. Louis, MO), 50 GYKI 52466 [1-(4-aminophenyl)-4-methyl-7,8-methylenedioxy-5H-2,3-benzodiazepine hydrochloride; Research Biochemicals, Natick, MA] or 50 GYKI 53655 [LY200168; 1-(4-aminophenyl)-3-methylcarbamyl-4-methyl-3,4dihydro-7,8-methylenedioxy-5H-2,3-benzodiazepine hydrochloride; Sigma], 10 (-)-bicuculline methiodide (Sigma); and 10 SCH 50911 (Tocris Cookson) to block NMDA, AMPA, $\mathrm{GABA}_{\mathrm{A}}$, and $\mathrm{GABA}_{\mathrm{B}}$ receptor currents, respectively. AMPA receptor currents were isolated by perfusing the same antagonist solution except that $10 \mu \mathrm{M}$ LY 293558 \{(3S,4aR,6R,8aR)-6-[2(1(2)H-tetrazole-5-yl)ethyl]-decahydroisoquinoline-3-carboxylic acid $\}$ was substituted for GYKI 52466 or GYKI 53655. Solution exchange was accomplished by closing the valve containing the control solution and opening another valve containing the antagonist solution. An equilibration time of $100 \mathrm{sec}$ was allowed when changing solutions. The dead volume was $<1-1.5 \mathrm{ml}$. Topiramate was dissolved in DMSO so that the final concentration was $<0.01 \%$, which did not affect GluR5 kainate-receptormediated responses. LY 293558, GYKI 53655, and topiramate were gifts, respectively, of Eli Lilly (Indianapolis, IN), Dr. Chris J. McBain (National Institute of Child Health and Human Development, Bethesda, MD), and Johnson \& Johnson Pharmaceutical Research and Development (Spring House, PA).

Statistical analysis. Currents were acquired using Clampex 8.03 (Axon Instruments) at a sampling rate of 4 or $5 \mathrm{kHz}$ and were ordinarily filtered using a four-pole Bessel filter with a corner frequency of $2 \mathrm{kHz}$ and 80 $\mathrm{db} /$ decade attenuation, except when acquiring mEPSCs, in which case an eight-pole Bessel filter (Model 900; Frequency Devices, Haverhill, MA) was used, with a corner frequency of $1 \mathrm{kHz}$. The signals were stored directly to a computer hard disk for later for analysis using Clampfit (Axon Instruments). The rectification index (RI) was calculated according to the formula of Ozawa et al. (1991): RI $=\left[I_{+40} /\left(40-E_{\text {rev }}\right)\right] /\left[I_{-60} /\right.$ $\left.\left(-60-E_{\text {rev }}\right)\right]$, where $I_{+40}$ and $I_{-60}$ are the peak amplitudes of the GluR5 kainate receptor EPSCs at +40 and $-60 \mathrm{mV}$, respectively, and $E_{\text {rev }}$ is the reversal potential determined for the cell under study. mEPSCs were detected using the template detection feature of Clampfit 9.0. Origin (OriginLab, Northampton, MA) was used for final plotting.

\section{Results \\ GluR5 kainate-receptor-mediated synaptic responses evoked by EC stimulation}

In whole-cell recordings from 18 BLA principal neurons (Fig. $1 A$ ) in separate slices, single-pulse stimulation of the EC in the absence of pharmacological antagonists evoked inward synaptic currents at a holding potential of $-60 \mathrm{mV}$ of mean peak amplitude $2212 \pm 280 \mathrm{pA}$. The mean $10-90 \%$ rise time was $2.8 \pm 0.4$ msec and the $90-10 \%$ decay time was $19.3 \pm 2.8 \mathrm{msec}$. Perfusion with solution containing $100 \mu \mathrm{M}$ AP5, $50 \mu \mathrm{M}$ GYKI 52466, $10 \mu \mathrm{M}$ bicuculline, and $10 \mu \mathrm{M}$ SCH 50911 resulted in a $70.8 \pm 3.2 \%$ reduction in the peak amplitude. In an additional four experiments in which $50 \mu \mathrm{M}$ GYKI 53655, a more potent AMPA receptor antagonist (Paternain et al., 1995; Wilding and Huettner, 1995), was substituted for GYKI 52466, there was a similar degree of inhibition of the peak response $(68.0 \pm 8.5 \%)$, confirming that AMPA receptors do not contribute to the residual component of the current. The resistant component of the total synaptic current was completely blocked in four slices by the decahydroisoquinoline-selective GluR5 kainate receptor antagonists LY 293558 (Bleakman et al., 2002), demonstrating that it is mainly attributable to the activation of GluR5 kainate receptors (Fig. $1 B)$. The decahydroisoquinoline-sensitive fraction of the EPSC representing the activation of GluR5 kainate receptors $(\sim 30 \%)$ is similar to that determined previously on the basis of currentclamp recordings in BLA principal neurons ( $\mathrm{Li}$ et al., 2001). The $10-90 \%$ rise time of the resistant current was $6.1 \pm 1.1 \mathrm{msec}$ ( $p<0.002$ with respect to total current) and the $90-10 \%$ decay time was $39.2 \pm 6.7 \mathrm{msec}(p<0.02)$. Thus, the time course of the 
A
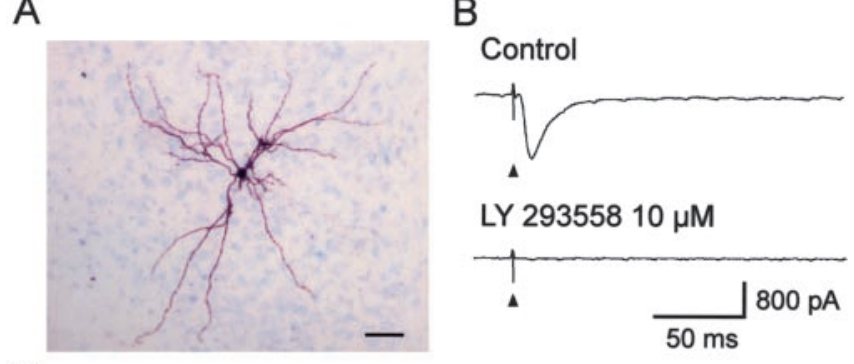

LY $29355810 \mu \mathrm{M}$
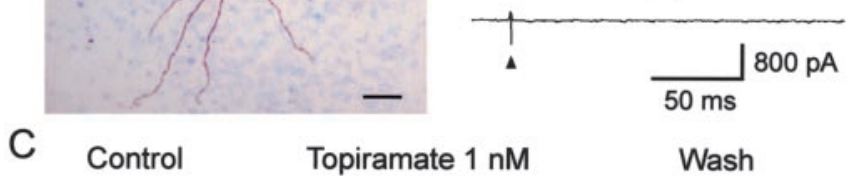

Topiramate $1 \mathrm{nM}$
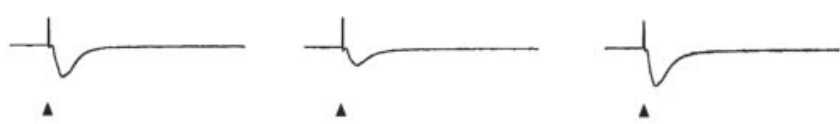

Control

Topiramate $1 \mu \mathrm{M}$
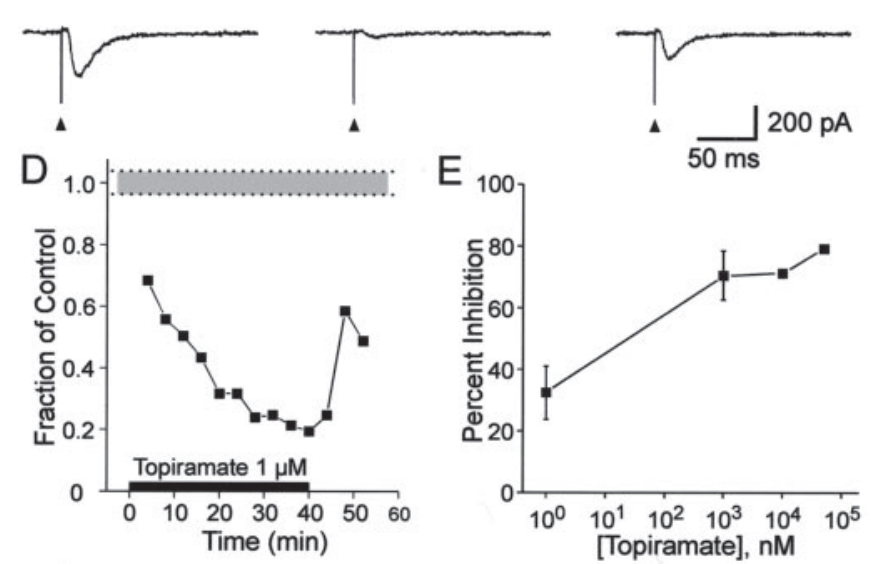

Figure 1. LY 293558 and topiramate block GluR5 kainate-receptor-mediated synaptic responses in BLA neurons. A, Typical biocytin-filled neuron in a slice stained for horseradish peroxidase and counterstained with cresyl violet. Scale bar, $100 \mu \mathrm{m}$. B, Synaptic responses were evoked by EC stimulation (triangles) in the presence of AP5, GYKI 52466, bicuculline, and SCH 50911. Perfusion for 10 min with $10 \mu M$ LY 293558 eliminated the residual synaptic response representing the component mediated by GluR5 kainate receptors. Holding potential, -60 $\mathrm{mV}$. C, Depression of GluR5 kainate receptor responses by $1 \mathrm{~nm}$ (top) and $1 \mu \mathrm{m}$ (bottom) topiramate. The topiramate traces were obtained $40 \mathrm{~min}$ after the onset of the topiramate perfusion; the wash traces were obtained $8-12$ min after the termination of the topiramate perfusion. Each trace is the average of the responses to 25 stimuli. D, Time course of the development of inhibition in the experiment with $1 \mu \mathrm{m}$ topiramate. Data points indicate mean peak amplitude values for 25 successive stimuli applied at 10 sec intervals normalized to the mean peak value before topiramate (SE indicated by gray band). E, Concentration-response curve for the inhibition of GluR5 kainate receptor current by various concentrations of topiramate. Each point represents the mean \pm SEM of the steady-state level of inhibition 20-60 min after the onset of topiramate perfusion in two to four experiments.

resistant current was significantly slower than that of the total current, as has been reported previously for kainate-receptormediated synaptic currents in other preparations (Castillo et al., 1997; Vignes and Collingridge, 1997). The synaptic response was outward at positive membrane potentials and the current-voltage relationship of the peak current showed a moderate voltage dependence, as indicated in Figure $2 D$, with a rectification index of $0.42 \pm 0.08$ (uncorrected $E_{\mathrm{r}},-17 \pm 5 \mathrm{mV}$; four cells), indicating inward rectification. The inward rectification suggests that GluR5 kainate receptors containing unedited GluR5 subunits contribute to the synaptic response (Burnashev et al., 1996; Lerma et al., 2001); this is compatible with the presence of unedited GluR5 mRNA in the BLA (Li et al., 2001).
A

Control

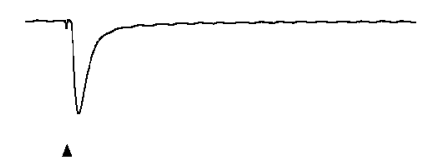

GYKI $5246650 \mu \mathrm{M}$

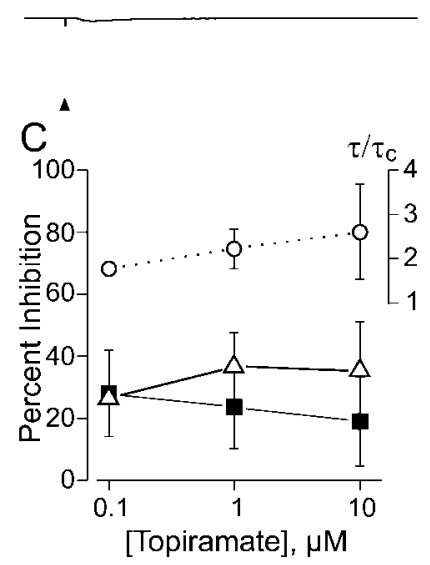

E

E Control

B Control

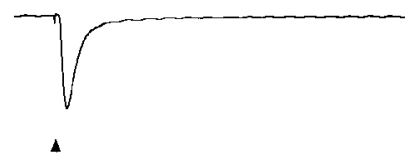

Topiramate $1 \mu \mathrm{M}$

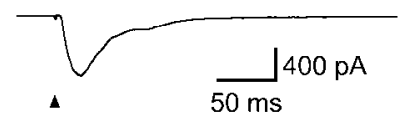

$\mathrm{D}$

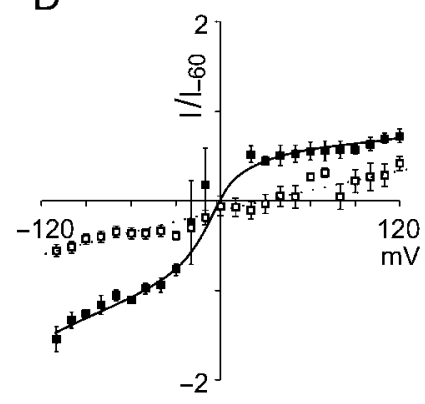

Topiramate $1 \mu \mathrm{M}$

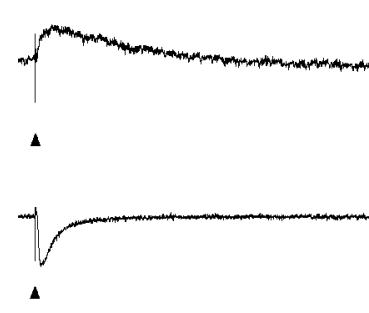

$+80 \mathrm{mV}$

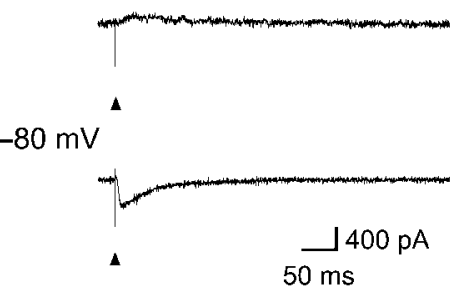

Figure 2. A, Block of predominantly AMPA-receptor-mediated synaptic current by $50 \mu \mathrm{m}$ GYKI 52466. The recording was performed in the presence of AP5, LY 293558, bicuculline, and SCH 50911. B, Partial inhibition of the predominantly AMPA-receptor-mediated synaptic current by $1 \mu \mathrm{m}$ topiramate. Note the prolongation of the time course of the response in the presence of topiramate. In $A$ and $B$, each trace is the average of the responses to 25 stimuli. $C$, Concentration-response curves for topiramate inhibition of AMPA-receptor-mediated synaptic currents. Current decay in the presence of topiramate was fitted by a single exponential function; the fits for the responses to 25 successive stimuli were averaged. The percent inhibition of the peak current values (filled squares) and the zero time values from the exponential fits (open triangles) are plotted with respect to the left ordinate. The ratios of the decay time constant values from fits in the presence $(\tau)$ and absence $\left(\tau_{c}\right)$ of topiramate are plotted with respect to the right ordinate. Each point represents the mean \pm SEM of values from two to four experiments. D, Voltage dependence of evoked GluR5 kainate-receptor-mediated synaptic currents. The peak amplitude of synaptic responses in the absence (filled squares) and presence (open squares) of $1 \mu$ m topiramate was determined at various holding potential levels and normalized to the control value for that cell at $-60 \mathrm{mV}\left(I_{-60}\right)$. Each point represents the mean \pm SEM of three control values and seven topiramate values from three cells. The fits are arbitrary. $E$, Sample traces comparing the inhibitory action of topiramate on evoked GluR5 kainate receptor currents at -80 and $+80 \mathrm{mV}$.

\section{Topiramate reduces GluR5 kainate-receptor-mediated synaptic currents}

Perfusion with topiramate ( $1 \mathrm{nM}$ to $50 \mu \mathrm{M}$ ) caused a slow reduction in the amplitude of the GluR5 kainate-receptor-mediated synaptic response. There was a rapid partial depression in the peak amplitude (within 4 min after the onset of perfusion); however, maximum blockade required 40 to $50 \mathrm{~min}$ to develop (Fig. $1 D$ ). When stable recordings could be maintained for a sufficiently long period, slow recovery was obtained over the course of 5 to $30 \mathrm{~min}$ (Fig. 1C,D). The concentration dependence of the 
A Control

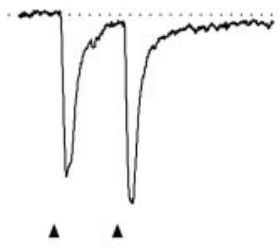
Topiramate $10 \mu \mathrm{M}$

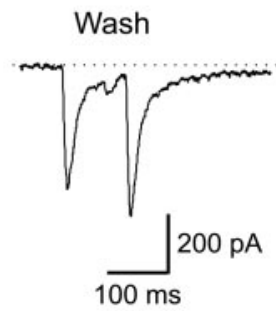

B

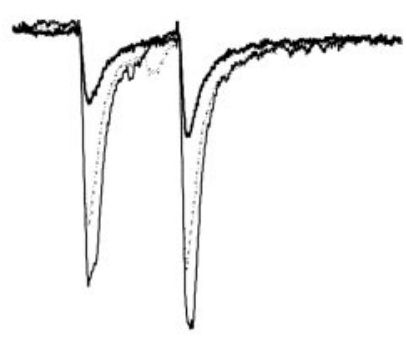

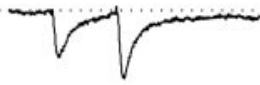

C

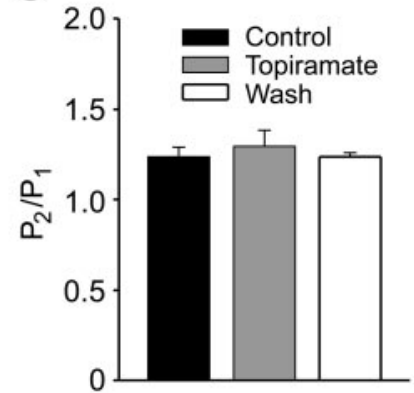

Figure 3. Effect of topiramate on paired-pulse facilitation of GluR5 kainate-receptormediated evoked synaptic currents. $A$, Perfusion with $10 \mu \mathrm{m}$ topiramate substantially reduces the amplitude of both responses ( $40 \mathrm{~min}$ after onset of perfusion) with partial recovery during wash (12 min after termination of topiramate). Triangles indicate paired-pulse stimulation. $B$, Superposition of control, topiramate, and wash traces from $A$. C, Summary of data from four separate experiments similar to that shown in $A$. Each bar represents the ratio $\left(P_{2} / P_{1}\right)$ of the peak amplitudes of the synaptic responses to the second stimulus and the first stimulus. There is no significant difference between the control, topiramate, and wash values.

topiramate blocking effect is shown in Figure $1 \mathrm{E}$. Modest inhibition was observed at concentrations as low as $1 \mathrm{nM}$. However, even at the maximum concentration tested $(50 \mu \mathrm{M})$ there was incomplete bock (79\% inhibition). The $50 \%$ blocking concentration $\left(\mathrm{IC}_{50}\right.$ ) determined by interpolation was $0.46 \mu \mathrm{M}$. Topiramate did not significantly affect the $10-90 \%$ rise time or the $90-10 \%$ decay time of the synaptic current, which was $10.4 \pm 2.3$ and $36.0 \pm 3.9 \mathrm{msec}$ for $1 \mu \mathrm{M}$ topiramate and $5.0 \pm 1.3$ and $21.7 \pm 2.1$ msec for $10 \mu \mathrm{M}$ topiramate.

\section{Voltage dependence of topiramate block}

Figure $2 D$ shows the voltage dependence of the synaptic current amplitude before and after perfusion with $1 \mu \mathrm{M}$ topiramate (sample traces are illustrated in Fig. 2E). Topiramate reduced the synaptic current amplitude at all membrane potentials approximately equally (i.e., plots of the calculated fractional block values vs membrane potential had slopes that were not significantly different from 0). Topiramate, a sulfamate ester, is a weak acid $\left(\mathrm{pK}_{\mathrm{a}}, 8.66\right)$ (Maryanoff et al., 1998) that is predicted to be $5 \%$ negatively charged at a physiological $\mathrm{pH}$ of 7.4 . If the charged form of topiramate interacts with the GluR5 kainate receptor, and if this interacting site is within the membrane electric field, the block would be relieved by depolarization. Therefore, the lack of voltage dependence is consistent with the possibility that the more abundant neutral form of the molecule is the active species and also with the hypothesis (see Discussion) that topiramate acts indirectly through a non-kainate-receptor target molecule.

\section{Selectivity of topiramate block}

AMPA-receptor-mediated synaptic currents were recorded with the same mixture of antagonists used for GluR5 kainate receptor responses, except that GYKI 52466 was omitted and replaced by
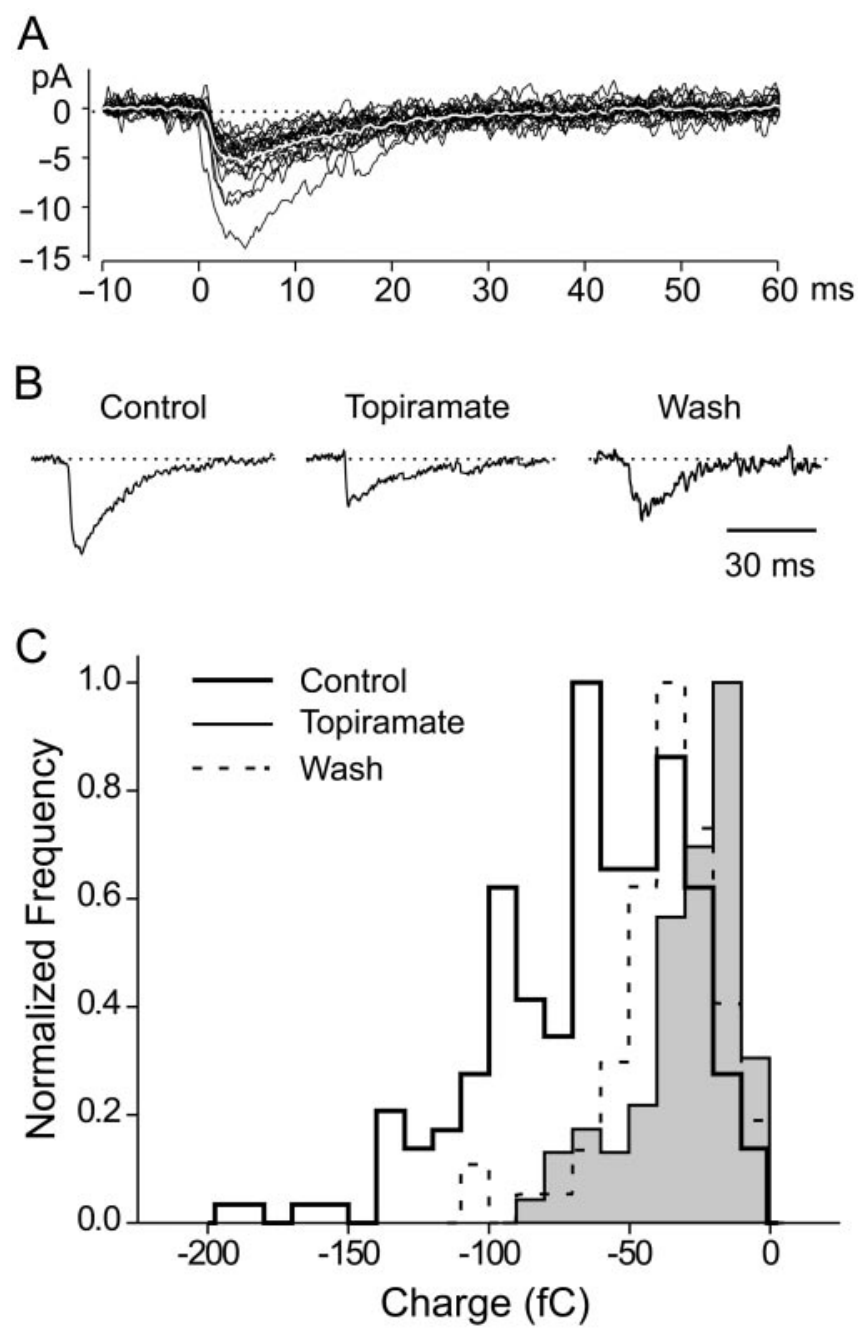

Figure 4. Effect of topiramate on spontaneous GluR5 kainate-receptor-mediated mEPSCs in a BLA neuron. The recording was performed in the presence of $100 \mu \mathrm{M} \mathrm{AP5,} 50 \mu \mathrm{M}$ GYKI 52466, $10 \mu \mathrm{m}$ bicuculline, $10 \mu \mathrm{m} \mathrm{SCH} 50911$, and $1 \mu \mathrm{m}$ tetrodotoxin. A, Twenty representative aligned $\mathrm{mEPSCs}$; the white trace is the average. $B$, Averages of $20 \mathrm{mEPSC}$ before and $15 \mathrm{~min}$ after onset of $10 \mu \mathrm{m}$ topiramate perfusion, and immediately after the termination of the perfusion (wash). C, mEPSCs during 15 min epochs were collected and the area (representing the charge) was determined by integration over a $60 \mathrm{msec}$ period. The histogram plots the normalized integrated charge values for mEPSCs collected under the conditions as in $B$. mEPSCs were detected in a nonbiased manner using a scaled template procedure based on an average of five control $\mathrm{mEPSC}$. Mean \pm SE rise and decay time constants were control: $7.2 \pm 0.2$ and $23.6 \pm 0.8$ $(n=480)$; topiramate: $4.9 \pm 0.2$ and $16.5 \pm 0.4(n=561)$; wash: $8.2 \pm 0.7$ and $34.2 \pm 3.4$ $(n=73)$. Gaussian fits to the control, topiramate, and wash histograms gave center values of $56.0,4.8$, and $33.4 \mathrm{fC}$. Similar results were obtained in five additional experiments.

LY 293558. Under these conditions, the mean peak current amplitude was $1594 \pm 398 \mathrm{pA}$, the mean $10-90 \%$ rise time was $7.7 \pm$ $4.8 \mathrm{msec}$ and the mean $90-10 \%$ decay time was $23.2 \pm 4.6 \mathrm{msec}$ (seven slices); the mean decay time constant value $\left(\tau_{\mathrm{c}}\right)$ from single exponential fits was $11.6 \pm 1.4 \mathrm{msec}$. Topiramate $(0.1-10 \mu \mathrm{M})$ caused a modest reduction in the peak current amplitude that was not concentration-dependent and a slightly greater inhibition of the zero time values from exponential fits to the decays (Fig. $2 B, C)$. There was a concentration-dependent slowing in the fitted time constant values ( $p=0.017$, paired $t$ test)

\section{Paired-pulse facilitation}

Repetitive EC stimulation with an interstimulus interval of 100 msec was associated with an enhancement of the second evoked 
synaptic response by $23.6 \pm 0.1 \%$ compared with the first (four slices). Topiramate $(10 \mu \mathrm{M})$ markedly depressed the amplitudes of both responses, but did not cause a significant change in the degree of facilitation (Fig. 3). These results are consistent with the possibility that topiramate acts postsynaptically to reduce the GluR5 kainate-receptor-mediated synaptic responses.

\section{Miniature synaptic currents}

To further investigate the possible postsynaptic locus of action of topiramate, we examined the effects of $1 \mu \mathrm{M}$ topiramate on spontaneous mEPSCs mediated by pharmacologically isolated GluR5 kainate receptors in the presence of $100 \mu \mathrm{M}$ AP5, $50 \mu \mathrm{M}$ GYKI 52466, $10 \mu \mathrm{M}$ bicuculline, $10 \mu \mathrm{M}$ SCH 50911, and $1 \mu \mathrm{M}$ tetrodotoxin. mEPSCs were acquired in 15 min epochs. As shown in Figure 4, topiramate was associated with a rightward shift in the charge distribution histogram, so that there was a $91 \%$ reduction in the central value compared with control and partial recovery to $60 \%$ of the control central value during wash. Topiramate did not reduce the mEPSC frequency (control, $0.278 / \mathrm{sec}$; topiramate, $0.316 / \mathrm{sec}$ ). Topiramate was associated with a modest speeding of the fitted single exponential mEPSC rise and decay times (32 and $30 \%$, respectively) with recovery during wash.

\section{Discussion}

In this study, we have shown that topiramate selectively inhibits the component of the excitatory synaptic response in BLA principal neurons that is mediated by pharmacologically defined GluR5 kainate receptors and has a weaker, but still significant, depressant action on synaptic responses predominantly mediated by AMPA receptors. This supports the concept that topiramate is an antagonist of excitatory synaptic transmission through effects on AMPA and kainate receptors (Gibbs et al., 2000; Skradski and White, 2000) and suggests that kainate receptors could be a more important target than AMPA receptors. GluR5 kainate receptor responses were highly sensitive to topiramate, with a $50 \%$ reduction in the current amplitude occurring in the range of $\sim 0.5 \mu \mathrm{M}$. The topiramate concentrations producing $>50 \%$ block of GluR5 kainate-receptor-mediated responses correspond well with trough topiramate serum concentrations associated with antiepileptic efficacy in clinical trials of $2-12 \mu \mathrm{g} / \mathrm{ml}(5.9-$ $35.4 \mu \mathrm{M}$ ) (Twyman et al., 1999; May et al., 2002). This indicates that GluR5 kainate receptors are likely to be substantially blocked during topiramate therapy at clinically effective doses. In contrast, AMPA receptor responses are reduced much more modestly at these concentrations. This is not surprising because AMPA receptors are crucial for excitatory synaptic transmission throughout the CNS, and their blockade would be expected to produce dramatic neurobehavioral impairment, which does not occur with topiramate at therapeutic doses.

In addition to its anticonvulsant activity, there is evidence that topiramate may be efficacious in the treatment of chronic pain syndromes, including neuropathic pain (Chong and Libretto, 2003). In this context, it is interesting that selective GluR5 kainate receptor antagonists exhibit antinociceptive activity in models of persistent nociceptive activation (Simmons et al., 1998), suggesting that the GluR5 kainate blocking action could play a role in the antinociceptive action of topiramate.

Topiramate caused a marked prolongation of the duration of AMPA-receptor-mediated synaptic currents at all concentrations tested. The basis for this action was not determined, but could be attributable to effects on AMPA receptor desensitization, as occurs with drugs such as cyclothiazide (Patneau et al., 1993; Wong and Mayer, 1993) and other sulfonamides (Quirk and Nisen- baum, 2002) that differentially reduce the desensitization of AMPA, but not kainate receptors. In this regard, it is notable that both topiramate and the sulfonamide desensitization modulators contain an aminosulfonyl functional group. Because cyclothiazidelike desensitization modulators increase the peak amplitude of AMPA receptor currents (Rammes et al., 1998), it is interesting to speculate that the differential topiramate sensitivity of AMPA and kainate receptors could be attributable to the selective reversal of AMPA but not kainate receptor block as a result of reduced desensitization. According to this hypothesis, topiramate would affect AMPA and kainate receptors similarly by interacting with a common blocking mechanism; however, the depression of AMPA receptor responses would be partially offset by a distinct effect on desensitization.

The inhibitory action of topiramate developed relatively slowly, requiring $30 \mathrm{~min}$ or more to achieve its full extent. In in vitro studies, topiramate often exhibits such delayed actions; this has been taken as evidence that the drug acts indirectly. For example, it has been suggested that topiramate may act on protein kinases to modify the phosphorylation state of the various receptors and ion channels with which it interacts, thereby altering their activity (Shank et al., 2000; White, 2002). The lack of voltage dependence of the topiramate blocking action is compatible with such an indirect action.

The selectivity of the action of topiramate on GluR5 kainate receptors versus AMPA receptors suggests that the drug acts postsynaptically. This is supported by our results with paired-pulse facilitation and mEPSCs. However, we note that topiramate, at somewhat higher but still clinically relevant concentrations, has been reported to inhibit voltage-activated $\mathrm{Na}^{+}$channels in a use-dependent manner (Zona et al., 1997; Taverna et al., 1999). $\mathrm{Na}^{+}$-channel blocking antiepileptic drugs may act in part by inhibiting glutamate release (Rogawski, 2002). Therefore, in addition to its postsynaptic actions on kainate and AMPA receptors, topiramate could, under some circumstances, also affect excitatory neurotransmission through a presynaptic action.

In conclusion, the observation that topiramate, a widely used antiepileptic agent, selectively blocks excitatory synaptic transmission mediated by GluR5 kainate receptors supports the concept that GluR5 kainate receptors could represent a novel target for antiepileptic drug development. Because selective GluR5 kainate receptor antagonists can protect against seizures in animal models without acute CNS toxicity (Smolders et al., 2002), antiepileptic drugs that interact with GluR5 kainate receptors could protect against seizures without the untoward effects that result from the blockade of other ionotropic glutamate receptors (Löscher and Rogawski, 2002).

\section{References}

Bleakman D, Lodge D (1998) Neuropharmacology of AMPA and kainate receptors. Neuropharmacology 37:1187-1204.

Bleakman D, Gates MR, Ogden AM, Mackowiak M (2002) Kainate receptor agonists, antagonists and allosteric modulators. Curr Pharm Des 8:873-885.

Burnashev N, Villarroel A, Sakmann B (1996) Dimensions and ion selectivity of recombinant AMPA and kainate receptor channels and their dependence on Q/R site residues. J Physiol (Lond) 496 (Pt 1):165-173.

Castillo PE, Malenka RC, Nicoll RA (1997) Kainate receptors mediate a slow postsynaptic current in hippocampal CA3 neurons. Nature 388:182-186.

Chong MS, Libretto SE (2003) The rationale and use of topiramate for treating neuropathic pain. Clin J Pain 19:59-68.

Donevan SD, Rogawski MA (1995) Intracellular polyamines mediate inward rectification of $\mathrm{Ca}^{2+}$-permeable $\alpha$-amino-3-hydroxy-5-methyl-4isoxazolepropionic acid receptors. Proc Natl Acad Sci USA 92:9298-9302. 
Gibbs 3rd JW, Sombati S, DeLorenzo RJ, Coulter DA (2000) Cellular actions of topiramate: blockade of kainate-evoked inward currents in cultured hippocampal neurons. Epilepsia 41 [Suppl 1]:S10-S16.

Glauser TA (1999) Topiramate. Epilepsia 40 [Suppl 5]:S71-S80.

Jette NJ, Marson AG, Hutton JL (2002) Topiramate add-on for drugresistant partial epilepsy. Cochrane Database Syst Rev 3:CD001417.

Kamboj SK, Swanson GT, Cull-Candy SG (1995) Intracellular spermine confers rectification on rat calcium-permeable AMPA and kainate receptors. J Physiol 486 (Pt 2):297-303.

Lerma J, Paternain AV, Rodríguez-Moreno A, López-García JC (2001) Molecular physiology of kainate receptors. Physiol Rev 81:971-998.

Li H, Rogawski MA (1998) GluR5 kainate receptor mediated synaptic transmission in rat basolateral amygdala in vitro. Neuropharmacology 37:1279-1286.

Li H, Chen A, Xing G, Wei ML, Rogawski MA (2001) Kainate receptormediated heterosynaptic facilitation in the amygdala. Nat Neurosci 4:612-620.

Löscher W, Rogawski MA (2002) Epilepsy. In: Ionotropic Glutamate Receptors as Therapeutic Targets (Lodge D, Danysz W, Parsons CG, eds), pp 91-132, Johnson City, TN: Graham.

Mahanty NK, Sah P (1998) Calcium-permeable AMPA receptors mediate long-term potentiation in interneurons in the amygdala. Nature 394:683-687.

Maryanoff BE, Costanzo MJ, Nortey SO, Greco MN, Shank RP, Schupsky JJ, Ortegon MP, Vaught JL (1998) Structure-activity studies on anticonvulsant sugar sulfamates related to topiramate. Enhanced potency with cyclic sulfate derivatives. J Med Chem 41:1315-1343.

May TW, Rambeck B, Jurgens U (2002) Serum concentrations of topiramate in patients with epilepsy: influence of dose, age, and comedication. Ther Drug Monit 24:366-374.

Ozawa S, Iino M, Tsuzuki K (1991) Two types of kainate response in cultured rat hippocampal neurons. J Neurophysiol 66:2-11.

Paternain AV, Morales M, Lerma J (1995) Selective antagonism of AMPA receptors unmasks kainate receptor-mediated responses in hippocampal neurons. Neuron 14:185-189.

Patneau DK, Vyklicky L Jr, Mayer ML (1993) Hippocampal neurons exhibit cyclothiazide-sensitive rapidly desensitizing responses to kainate. J Neurosci 13:3496-3509.

Quirk JC, Nisenbaum ES (2002) LY404187: a novel positive allosteric modulator of AMPA receptors. CNS Drug Rev 8:255-282.

Rammes G, Swandulla D, Spielmanns P, Parsons CG (1998) Interactions of GYKI 52466 and NBQX with cyclothiazide at AMPA receptors: experiments with outside-out patches and EPSCs in hippocampal neurones. Neuropharmacology 37:1299-1320.

Rogawski MA (2002) Principles of antiepileptic drug action. In: Antiepileptic drugs, Ed 5 (Levy RH, Mattson RH, Meldrum BS, Perucca E, eds), pp 3-22, Philadelphia: Lippincott Williams \& Wilkins.

Shank RP, Gardocki JF, Streeter AJ, Maryanoff BE (2000) An overview of the preclinical aspects of topiramate: pharmacology, pharmacokinetics, and mechanism of action. Epilepsia 41[Suppl 1]:S3-S9.
Simmons RMA, Li DL, Hoo KH, Deverill M, Ornstein PL, Iyengar S (1998) Kainate GluR5 receptor subtype mediates the nociceptive response to formalin in the rat. Neuropharmacology 37:25-36.

Skradski S, White HS (2000) Topiramate blocks kainate-evoked cobalt influx into cultured neurons. Epilepsia 41 [Suppl 1]:S45-S47.

Smith L, Price-Jones M, Hughes K, Egebjerg J, Poulsen F, Wiberg FC, Shank RP (2000) Effects of topiramate on kainate- and domoate-activated $\left[{ }^{14} \mathrm{C}\right]$ guanidinium ion flux through GluR6 channels in transfected BHK cells using Cytostar-T scintillating microplates. Epilepsia 41 [Suppl 1]:S48-S51.

Smolders I, Bortolotto ZA, Clarke VR, Warre R, Khan GM, O’Neill MJ, Ornstein PL, Bleakman D, Ogden A, Weiss B, Stables JP, Ho KH, Ebinger G, Collingridge GL, Lodge D, Michotte Y (2002) Antagonists of $\mathrm{GLU}_{\mathrm{K} 5}{ }^{-}$ containing kainate receptors prevent pilocarpine-induced limbic seizures. Nat Neurosci 5:796-804.

Swanson LW, Petrovich GD (1998) What is the amygdala? Trends Neurosci 21:323-331.

Taverna S, Sancini G, Mantegazza M, Franceschetti S, Avanzini G (1999) Inhibition of transient and persistent $\mathrm{Na}^{+}$current fractions by the new anticonvulsant topiramate. J Pharmacol Exp Ther 288:960-968.

Tóth K, McBain CJ (1998) Afferent-specific innervation of two distinct AMPA receptor subtypes on single hippocampal interneurons. Nat Neurosci 1:572-578.

Twyman RE, Ben-Menachem E, Veloso F, Bomhof MAM, Wu SC, Pledger G (1999) Plasma topiramate (TPM) concentration vs. therapeutic response during monotherapy. Epilepsia 40[Suppl 7]:111-112.

Vignes M, Collingridge GL (1997) The synaptic activation of kainate receptors. Nature 388:179-182.

White HS, Brown SD, Woodhead JH, Skeen GA, Wolf HH (1997) Topiramate enhances GABA-mediated chloride flux and GABA-evoked chloride currents in murine brain neurons and increases seizure threshold. Epilepsy Res 28:167-179.

White HS, Brown SD, Woodhead JH, Skeen GA, Wolf HH (2000) Topiramate modulates GABA-evoked currents in murine cortical neurons by a nonbenzodiazepine mechanism. Epilepsia 41[Suppl 1]:S17-S20.

White HS (2002) Topiramate. Mechanisms of action. In: Antiepileptic drugs, Ed 5 (Levy RH, Mattson RH, Meldrum BS, Perucca E, eds), pp 719-726, Philadelphia: Lippincott Williams \& Wilkins.

Wilding TJ, Huettner JE (1995) Differential antagonism of $\alpha$-amino-3hydroxy-5-methyl-4-isoxazolepropionic acid-preferring and kainatepreferring receptors by 2,3-benzodiazepines. Mol Pharmacol 47:582-587.

Wong LA, Mayer ML (1993) Differential modulation by cyclothiazide and concanavalin A of desensitization at AMPA- and kainate-preferring glutamate receptors. Mol Pharmacol 44:504-510.

Zhang X, Velumian AA, Jones OT, Carlen PL (2000) Modulation of highvoltage-activated calcium channels in dentate granule cells by topiramate. Epilepsia 41[Suppl 1]:S52-S60.

Zona C, Ciotti MT, Avoli M (1997) Topiramate attenuates voltage-gated sodium currents in rat cerebellar granule cells. Neurosci Lett 231:123126 